\title{
STRATEGI KOMUNIKASI INSTRUKSIONAL WIDYAISWARA LEMBAGA PENJAMINAN MUTU PENDIDIKAN BENGKULU DALAM PEMBELAJARAN
}

Oleh:

\author{
TITIK FITRIA HANDAYANI, HENNY AFRIANTI, SYISVA NURWITA \\ Program Studi Ilmu Komunikasi Fakultas Ilmu-Ilmu Sosial UNIVED Bengkulu
}

\begin{abstract}
This study aimed to find out thein structional communication strategy of Widyaiswara Education Quality Assurance Agency Bengkulu in learning, includesthe preInstructional strategies, the implementationof Instructional strategies, and the results and evaluation of in structional communication strategy. Thisresearchis aqualitative descriptive study. Datawere collected through observation, interviews and documentation. Data analysis was performed with Miles and Huberman(1984) data analysis techniques, namely: data collection, data reduction, data display, and drawing and verification conclution. The results showed: 1) In Pre-Instructional phase, Widyaiswara'sBengkuludo: preparationto implement thetrainingas indicated bya letter of assignmentand directionofthe management, arrange the Learning Implementation Plan(RPP) and Learning Syllabus, develop strategieswill be run in training, studying the entering behaviorand the prior needs oftraining participants during the training. In Instructionalphase the stepsare: determiningthe formulation of the instructional objectivesof education and training, paid attention tothe validity and relevance ofthe material to be delivered to training participants, useda variety of learningmediain the learning process, adapted the medium usedto learning objectives, useda variety of methodsin the learning process, established the source/teaching materialsin accordance withthe needs of training participants, determined appropriate time and appropriate objectives to achieve, encouraged the training participants to actively involve in the learning process. At the stage of evaluation, the steps are: evaluation oftrainingparticipantsin the form of assessmentat the end and assessment during the training through thetest questions.
\end{abstract}

Keywoords: Strategy, Communication, Widyaswara

\section{PENDAHULUAN}

Widyaiswara adalah Pegawai Negeri Sipil yang diberi tugas, tanggung jawab, wewenang dan hak oleh pejabat yang berwenang untuk mendidik, mengajar, dan/atau melatih secara penuh pada unit pendidikan dan pelatihan instansi pemerintah dan non pemerintah sebagaimana dikeluarkan oleh Lembaga
Administrasi Negara (LAN, 1997:23). Widyaiswara adalah jabatan fungsional yang mempunyai ruang lingkup, tugas, tanggung jawab, dan wewenang untuk mendidik, mengajar dan/atau melatih PNS pada Lembaga Diklat Pemerintah (Permenpan No. 14 tahun 2009).

Widyaiswara dalam kegiatan diklat merupakan guru/pemateri kelompok fungsional yang mempunyai peranan yang 
sangat besar dalam pembentukan sikap mental dan kualitas intelektual peserta diklat. Tugas yang diemban oleh widyaiswara adalah memfasilitasi sasaran didik dalam meningkatkan pengetahuan dan keterampilannya. Selain itu, Widyaiswara juga bertugas untuk membentuk kepribadian peserta diklat melalui pendidikan dan pelatihan yang dikomunikasikan secara verbal maupun nonverbal.

Apabila seorang widyaiswara yang terlibat dalam kegiatan pendidikan dan pelatihan memiliki kinerja baik, maka widyaiswara tersebut akan mampu meningkatkan kualitas pembelajaran pada kegiatan diklat.Dikatakan demikian karena widyaiswara yang memiliki kinerja baik dapat menyampaikan dan menjelaskan materi pelajaran dengan baik pula sehingga dapat membimbing dan mengarahkan peserta selama proses pembelajaran berlangsung.

Berangkat dari uraian di atas, artikel ini bertujuan ini untuk mengetahui strategi komunikasi instruksional Widyaiswara Lembaga Penjaminan Mutu Pendidikan Bengkulu dalam pembelajaran. Beberapa poin yang diuraikan dalam penelitian ini adalah: strategi Pra-Instruksional Widyaiswara Lembaga Penjaminan Mutu Pendidikan Bengkulu sebelum pembelajaran, strategi pelaksanaan Instruksional Widyaiswara Lembaga Penjaminan Mutu Pendidikan Bengkulu dalam Pembelajaran, serta hasil dan evaluasi dari strategi komunikasi instruksional Widyaiswara Lembaga Penjaminan Mutu Pendidikan Bengkulu dalam Pembelajaran.

\section{METODOLOGI PENELITIAN}

Penelitian iniadalah penelitian kualitatif dengan pendekatan deskriptif. Adapun yang dimaksud dengan penelitian kualitatif adalah penelitian yang bermaksud untuk memahami fenomena tentang apa yang dialami oleh subjek penelitian secara holistik, dan dengan cara deskripsi dalam bentuk kata-kata dan bahasa, pada suatu konteks khusus yang alamiah dan dengan memanfaatkan berbagai metode ilmiah (Moleong, 2007:6).

Penelitian ini dilaksanakan di Lembaga Penjaminan Mutu Pendidikan Bengkulu pada bulan Februari 2015 - Juli 2015. Data dikumpulkan melalui beberapa teknik, yaitu: observasi, wawancara mendalam, dan dokumentasi. Sementara itu, informan dipilih berdasarkan teknik purposive dengan sebaran berikut:

\begin{tabular}{|l|l|l|l|l|}
\hline No. & \multicolumn{1}{|c|}{$\begin{array}{c}\text { Nama } \\
\text { Informan }\end{array}$} & \multicolumn{1}{|c|}{ Jabatan } & Sex & Keterangan \\
\hline 1. & $\begin{array}{l}\text { Lanjar } \\
\text { Pramudi }\end{array}$ & Widyaiswara & Laki-Laki & $\begin{array}{l}\text { Informan } \\
\text { Pokok }\end{array}$ \\
\hline 2. & Edi Jatmiko & Widyaiswara & Laki-Laki & $\begin{array}{l}\text { Informan } \\
\text { Pokok }\end{array}$ \\
\hline 3. & Suardi & Widyaiswara & Laki-Laki & $\begin{array}{l}\text { Informan } \\
\text { pokok }\end{array}$ \\
\hline 4. & Marjuki & Widyaiswara & Laki-Laki & $\begin{array}{l}\text { Informan } \\
\text { Pokok }\end{array}$ \\
\hline 5. & Rusmanto & Widyaiswara & Laki-Laki & $\begin{array}{l}\text { Informan } \\
\text { Pokok }\end{array}$ \\
\hline 6. & $\begin{array}{l}\text { Muzanip } \\
\text { Alperi }\end{array}$ & Staf PMS & Laki-Laki & $\begin{array}{l}\text { Informan } \\
\text { Kunci }\end{array}$ \\
\hline 7. & $\begin{array}{l}\text { Sa'adah } \\
\text { Ridwan }\end{array}$ & $\begin{array}{l}\text { Kepala } \\
\text { LPMP }\end{array}$ & $\begin{array}{l}\text { Perempua } \\
\text { n }\end{array}$ & $\begin{array}{l}\text { Informan } \\
\text { Ahli }\end{array}$ \\
\hline 8. & $\begin{array}{l}\text { Bayu } \\
\text { Anggoro }\end{array}$ & $\begin{array}{l}\text { Peserta } \\
\text { Diklat }\end{array}$ & Laki-Laki & $\begin{array}{l}\text { Informan } \\
\text { Kunci }\end{array}$ \\
\hline 9. & $\begin{array}{l}\text { Endang } \\
\text { Setyaningsih }\end{array}$ & $\begin{array}{l}\text { Peserta } \\
\text { Diklat }\end{array}$ & $\begin{array}{l}\text { Perempua } \\
\text { n }\end{array}$ & $\begin{array}{l}\text { Informan } \\
\text { Kunci }\end{array}$ \\
\hline 10. & Normansyah & $\begin{array}{l}\text { Peserta } \\
\text { Diklat }\end{array}$ & Laki-Laki & $\begin{array}{l}\text { Informan } \\
\text { Kunci }\end{array}$ \\
\hline
\end{tabular}

Sumber: Data diolah, 2015

Penelitian kualitatif harus mengungkap kebenaran yang objektif. Karena itu keabsahan data dalam penelitian kualitatif sangat penting. Melalui keabsahan data kredibilitas (kepercayaan) penelitian 
kualitatif dapat tercapai. Dalam penelitian ini untuk mendapatkan keabsahan data dilakukan dengan triangulasi data dan triangulasi sumber. Triangulasi dapat dilakukan dengan teknik yang berbeda (Nasution, 2003:115) yaitu wawancara, observasi dan dokumen. Selain digunakan untuk mengecek kebenaran data, triangulasi juga dilakukan untuk memperkaya data. Menurut Nasution, selain itu triangulasi juga dapat berguna untuk menyelidiki validitas tafsiran peneliti terhadap data, karena itu triangulasi bersifat reflektif.Triangulasi dengan sumber artinya membandingkan dan mengecek balik derajat kepercayaan suatu informasi yang diperoleh melalui waktu dan alat yang berbeda dalam penelitian kualitatif (Patton, 1987:331).

Teknik analisis data yang digunakan dalam penelitian ini adalah teknik Miles and Huberman (1984) (dalam Sugiyono, 2008) yang memiliki 4 tahap:

1. Pengumpulan Data (Data Collection) Kegiatan pengumpulan data pada penelitian ini adalah dengan menggunakan wawancara dan studi dokumentasi.

1. Reduksi Data (Data Reduction)

Reduksi dilakukan sejak pengumpulan data dimulai dengan membuat ringkasan, mengkode, menelusur tema, membuat gugus-gugus, menulis memo dan sebagainya dengan maksud menyisihkan data/informasi yang tidak relevan

2. Display Data (penyajian data)

Display data adalah pendeskripsian sekumpulan informasi tersusun yang memberikan kemungkinan adanya penarikan kesimpulan dan pengambilan tindakan. Penyajian data kualitatif disajikan dalam bentuk teks naratif. Penyajiannya juga dapat berbentuk matrik, diagram, tabel dan bagan
3. Verifikasi dan Penegasan Kesimpulan (Conclution Drawing and Verification) Merupakan kegiatan akhir dari analisis data. Penarikan kesimpulan berupa kegiatan interpretasi, yaitu menemukan makna data yang telah disajikan. Antara display data dan penarikan kesimpulan terdapat aktivitas analisis data yang ada. Dalam pengertian ini analisis data kualitatif merupakan upaya berlanjut, berulang dan terus-menerus. Masalah reduksi data, penyajian data dan penarikan kesimpulan/verifikasi menjadi gambaran keberhasilan secara berurutan sebagai rangkaian kegiatan analisis yang terkait.

Selanjutnya data yang telah dianalisis, dijelaskan dan dimaknai dalam bentuk kata-kata untuk mendiskripsikan fakta yang ada di lapangan, pemaknaan atau untuk menjawab pertanyaan penelitian yang kemudian diambil intisarinya saja. Hasil penelitian didapat dari wawancara yang dilaksanakan terhadap 10(sepuluh) informan penelitian.Data yang tidak terungkap melalui wawancara, dilengkapi dengan data hasil observasi langsung secara partisipatif yang dilakukan dalam rentang waktu pada bulan Februari sampai dengan April pada saat Diklat dilaksanakan. Untuk memperkuat substansi data hasil wawancara dan observasi, maka dilakukanlah penelusuran terhadap dokumen dan arsip yang ada.

\section{HASIL PENELITIAN DAN \\ PEMBAHASAN \\ Hasil Penelitian \\ Widyaiswara LPMP Bengkulu}

Untuk mengetahui keadaan widyaiswara LPMP Bengkulu serta kompetensi yang dimiliki, maka penulis melakukan wawancara dan studi dokumentasi dengan mengajukan beberapa pertanyaan penelitian kepada Kepala LPMP 
Bengkulu, sementara dokumentasi jumlah widyaiswara yang penulis peroleh dari bagian kepegawaian LPMP Bengkulu.

1. Jumlah widyaiswara yang dimiliki oleh LPMP Bengkulu

Dari dokumentasi yang diperoleh melalui bagian kepegawaian jumlah widyaiswara LPMP Bengkulu adalah 16 orang, yang terdiri dari: Widyaiswara Madya sebelas belas (11) orang dengan Gol. IV/a-IV/c, Widyaiswara Muda tiga (3) orang dengan Gol. III/c-Gol. IV/a dan Widyaiswara Pertama satu (1) orang.

2. Jumlah widyaiswara yang dimiliki oleh LPMP Bengkulu dengan mata pelajaran yang ada di sekolah

Dari dokumentasi yang diperoleh melalui bagian kepegawaian jumlah widyaiswara LPMP Bengkulu adalah 16 orang, dan sudah memenuhi semua mata pelajaran yang ada di sekolah.

3. Widyaiswara yang dimiliki oleh LPMP Bengkulu saat ini sudah memenuhi syarat untuk diangkat menjadi widyaiswara sesuai dengan aturan-aturan yang berlaku.

Hasil wawancara penulis dengan Kepala LPMP Bengkulu pada tanggal 13 April 2015 menjelaskan bahwa Widyaiswara yang dimiliki oleh LPMP Bengkulu sudah memenuhi syarat untuk diangkat menjadi widyaiswara sesuai dengan aturan-aturan yang berlaku. Seperti dalam kutipan wawancara berikut:

"Widyaiswara yang kita miliki saat ini telah memenuhi kriteria dan syarat untuk menjadi widyaiswara, proses seleksinya pun sangat ketat, dimulai dari analisis kebutuhan oleh LPMP Bengkulu, kemudian kebutuhan tersebut diajukan ke pusat, selanjutnya calon widyaiswara mengajukan permohonan ke LPMP Bengkulu.
Setelah berkas dinyatakan lengkap oleh LPMP Bengkulu, seterusnya kepala LPMP merekomendasikan calon widyaiswara tersebut ke Lembaga Administrasi Negara (LAN) dan terakhir Lembaga Administrasi Negara (LAN) dinyatakan lulus syarat administrasi dan uji/evaluasi kompetensi melalui paparan spesialisasi mata diklat"

4. Widyaiswara yang dimiliki oleh LPMP Bengkulu memenuhi kualifikasi pendidikan seperti yang dipersyaratkan oleh undang-undang atau aturan-aturan yang berlaku. Kepala LPMP Bengkulu selanjutnya menjelaskan:

"Widyaiswara yang kita miliki saat ini telah memenuhi kualifikasi pendidikan sesuai dengan undangundang dan aturan-aturan yang berlaku, Lebih lanjut kepala LPMP menjelaskan bahwa Lembaga Administrasi Negara (LAN) telah mengeluarkan persyaratan secara akademis untuk menjadi widyaiswara"

5. Widyaiswara yang dimiliki oleh LPMP Bengkulu saat ini memiliki kompetensi yang sesuai dengan kebutuhan LPMP Bengkulu.

Mengenai kompetensi widyaiswara Kepala LPMP Bengkulu menjelaskan:

"Karena widyaiswara yang kita kualifikasi pendidikan nya telah sesuai dengan persyaratan secara akademis, tentu kompetensinya pun tidak diragukan lagi untuk menjadi widyaiswara"

6. Kepala LPMP mengikuti Perkembangan widyaiswara dalam menjalankan tugasnya.

Kepala LPMP selalu memantau perkembangan widyaiswara dalam 
menjalankan tugasnya, seperti ungkapan Kepala LPMP Bengkulu berikut ini:

"Widyaiswara secara struktural berada langsung dibawah saya, sehingga saya selalu memantau dan menanyakan kepada widyaiswara bersangkutan tentang berbagai hal yang menyangkut dengan tugas dan tanggung jawab widyaiswara, sesekali saya juga melihat langsung ke dalam kelas ketika widyaiswara mengajar"

7. Evaluasi yang dilakukan terhadap widyaiswara

Evaluasi terhadap widyaiswara menurut Kepala LPMP tidak mengevaluasi secara langsung, seperti penjelasan Kepala LPMP Bengkulu berikut ini:

"Kalau evaluasi saya tidak secara langsung melakukan evaluasi, evaluasi dilakukan oleh evaluator yang ada di seksi Pemetaan Mutu dan Supervisi (PMS) dengan membuat instrument kepada peserta Diklat, saya hanya menegur secara lisan kalau ada widyaiswara yang dilaporkan tidak berkompeten dalam mengajar, untuk mengetahui bagaimana evaluasi terhadap widyaiswara ini coba hubungi seksi PMS"

Untuk meyakinkan tentang evaluasi terhadap widyaiswara, penulis menghubungi salah seorang staf evaluator Muzanip Alperi (13 April) untuk mengetahui bagaimana proses evaluasi yang dilakukan, wawancara penulis dengan Muzanip Alperi seperti kutipan dibawah ini:

"Evaluasi yang kita lakukan terhadap Widyaiswara dengan membuat instrument untuk diisi oleh peserta Diklat, bentuk evaluasi yang dilakukan oleh

\section{Seksi PMS adalah evaluasi terhadap Nara Sumber (Widyaiswara) dan evaluasi kepuasaan pelanggan terhadap pelayanan yang diberikan oleh LPMP"}

8. Penilaian khusus yang diberikan terhadap perilaku widyaiswara dalam menjalankan tugasnya

Kepala LPMP Bengkulu menjelaskan:

"Tidak ada perlakuan khusus yang diberikan oleh kepala kepada widyaiswara, semua widyaiswara saya perlakukan sama, kalau ada Diklat saya sesuaikan dengan kompetensi yang dimiliki oleh widyaiswara yang bersangkutan, dan tidak menonjolkan widyaiswara tertentu saja dalam menjalankan tugas."

9. Penghargaan dan kompensasi yang serta bentuk penghargaan yang diberikan Mengenai kompensasi dan penghargaan Kepala LPMP Bengkulu menjelaskan:

"Tidak ada penghargaan dan kompensasi secara khusus yang diberikan oleh kepala kepada widyaiswara, penghargaan dan kompensasi sifatnya hanya lisan saja dengan selalu melakukan komunikasi dengan widyaiswara setiap ada waktu luang"

Berdasarkan aspek dan teori yang penulis gunakan dalam ruang lingkup penelitian ini, Widyaiswara LPMP Bengkulu sudah melaksanakan tahapantahapan dalam strategi instruksional pada proses pembelajaran pada diklat yang dilaksanakan di LPMP Bengkulu yaitu Tahap Prainstruksional, Tahap Pelaksanaan Instruksional serta Tahap Penilaian dan Tindak Lanjut (Evaluasi). Hasil pengolahan data di lapangan dapat dirumuskan dalam bagan berikut: 


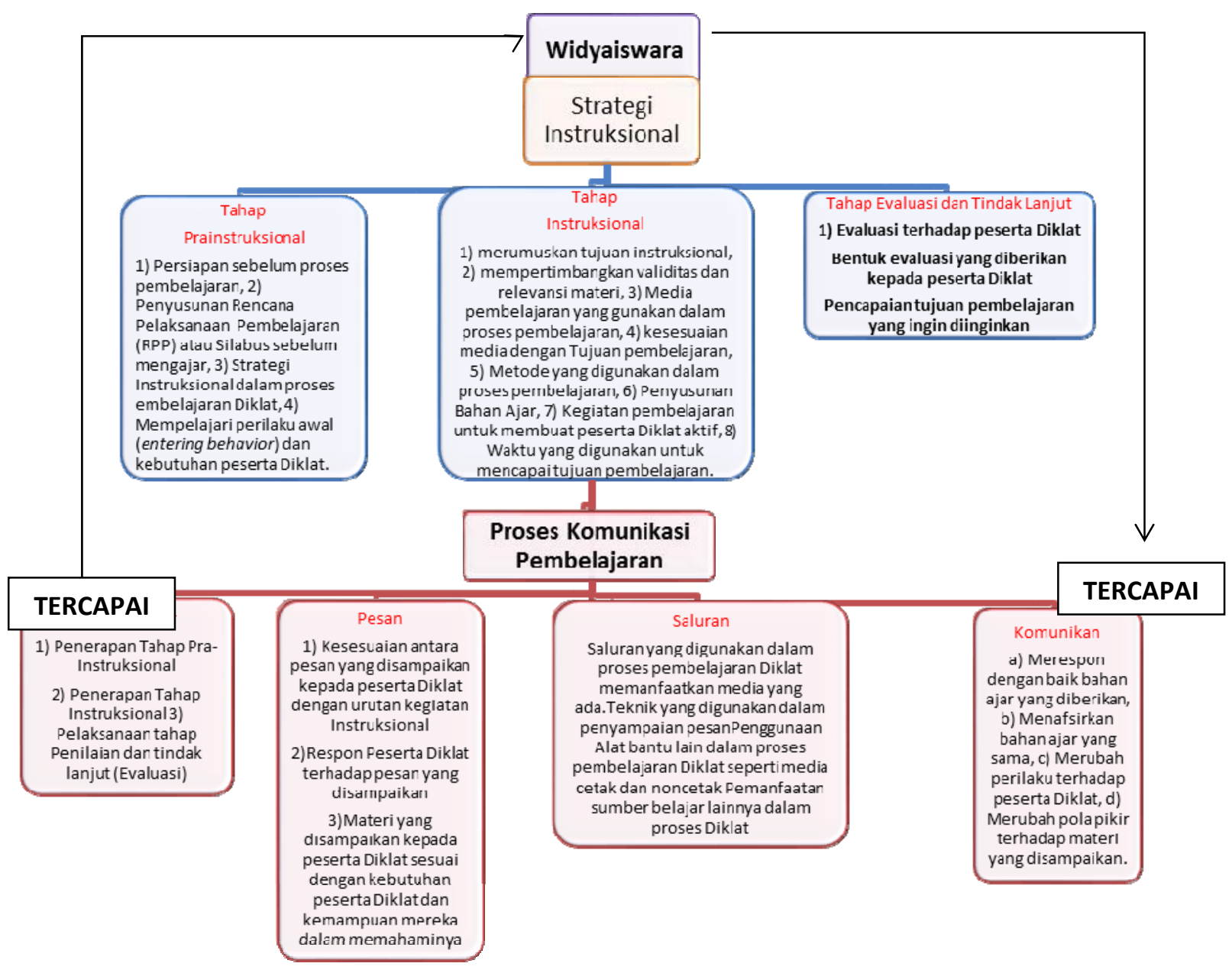

Gambar 5.1 Proses dan Hasil Penelitian

Sumber: Berdasarkan Hasil

Penelitian 2015

Gambar diatas menjelaskan Hasil penelitian yang telah dilakukan oleh penulis. Hasil penelitian tersebut di mulai dari Widyaiswara melaksanakan tugas nya, sebelum melaksanakan tugas widyaiswara terlebih dahulu mempersiapkan segala sesuatu yang dimasukkan ke dalam strategi instruksional dengan langkah PraInstruksional, Instruksional dan Evaluasi.
Langkah Pra-Instruksional adalah:1) Persiapan sebelum proses pembelajaran, 2) Penyusunan RPP dan Silabus, 3) Strategi khusus yang digunakan dalam proses pembelajaran dan 4) Mempelajari perilaku awal (entering behavior) dan kebutuhan peserta diklat.

Setelah semua langkah tersebut dilakukan dilanjutkan ke langkah Instruksional dimana widyaiswara LPMP Bengkulu melaksanakan tugas pembelajaran di kelas, dalam proses 
pembelajaran di kelas langkah-langkah yang dilakukan oleh widyaiswara LPMP Bengkulu adalah:1) Merumuskan tujuan instruksional, 2) Mempertimbangkan validitas dan relevansi materi, 3) Menggunakan Media pembelajaran dalam proses pembelajaran, 4) menyesuaikan media dengan Tujuan pembelajaran, 5) Menggunakan Metode dalam proses pembelajaran, 6) Menyusun Bahan Ajar, 7) Melakukan kegiatan pembelajaran untuk membuat peserta Diklat aktif, 8) Mengalokasikan Waktu yang tepat untuk mencapai tujuan pembelajaran. Selanjutnya dalam kerangka pemikiran juga digambarkan proses evaluasi yang dijalankan oleh widyaiswara Berdasarkan hasil wawancara penulis terhadap widyaiswara tentang evaluasi yang dilaksanakan dapat disimpulkan bahwa widyaiswara melakukan evaluasi dengan dua cara yaitu selama proses diklatberlangsung dan diakhir dengan menggunakan soal tes.

Pada gambar 5.1 diatas juga tergambar Proses Komunikasi Instruksional yang dijalankan. Dalam Proses Komunikasi Instruksional terdapat komponen komunikator, pesan, saluran dan komunikan.

Berdasarkan hasil penelitian komunikator telah menjalankan tahap-tahap dalam proses instruksional, dengan menyesuaikan antara pesan yang disampaikan kepada peserta Diklat dengan urutan kegiatan Instruksional, para peserta diklat telah merasa bahwa widyaiswara dalam menyampaikan pesan telah mengikuti urutan Instruksional serta Materi yang disampaikan kepada peserta Diklat sesuai dengan kebutuhan peserta Diklat dan kemampuan mereka dalam memahaminya.

Selanjutnya saluran yang digunakan dalam proses pembelajaran Diklatmemanfaatkan media yang ada seperti laptop, LCD proyektor dan buku paket. Teknik yang digunakan dalam penyampaian pesan adalah dengan menggunakan saluran media dengan teknik perpaduan antara verbal dan nonverbal dan widyaiswara LPMP Bengkulu juga menggunakan Alat bantu lain dalam proses pembelajaran Diklat seperti media cetak dan noncetak serta memanfaatkan sumber belajar lainnya dalam proses Diklat seperti perpustakaan, kunjungan lapangan dan memanfaatkan layanan internet.

Hasil penelitian lain juga mengungkapkan bahwa Komunikan: a) Merespon dengan baik bahan ajar yang diberikan, b) Menafsirkan bahan ajar yang sama, c) Merubah perilaku terhadap peserta Diklat, d) Merubah pola pikir terhadap materi yang disampaikan.

\section{PEMBAHASAN \\ Tahap Pra-Instruksional}

Pada Tahap instruksional ada beberapa aspek yang harus diperhatikan sebelum proses pembelajaran berlangsung yaitu: 1) Persiapan sebelum proses pembelajaran, 2) Penyusunan RPP dan Silabus, 3) Strategi khusus yang digunakan dalam proses pembelajaran dan 4) Mempelajari perilaku awal (entering behavior) dan kebutuhan peserta Diklat.

Dari hasil wawancara, observasi dan studi dokumentasi yang diperoleh bahwa perencanaan dalam pembelajaran yang dilakukan oleh widyaiswara LPMP Bengkulu adalah mempersiapkan silabus dan rencana pelaksanaan pembelajaran (RPP) yang isinya memuat langkah-langkah yang akan dijalankan selama proses pembelajaran berlangsung. Hal ini sejalan dengan Peraturan Menteri Pendidikan Nasional RI Nomor 41 tahun 2007 tentang Standar Proses untuk penyusunan Silabus dan Rencana Pelaksanaan Pembelajaran (RPP). 
Dalam implementasi RPP berfungsi untuk mendorong widyaiswara agar siap dalam melakukan kegiatan pembelajaran, membentuk kompetensi dan karakter peserta diklat. Seperti yang disampaikan Mulyasa (2011:83) yang menyatakan RPP dan silabus berfungsi untuk mengefektifkan proses pembelajaran dan pembentukan kompetensi yang sesuai dengan apa yang direncanakan.

Perencanaan pembelajaran yang dibuat oleh widyaiswara LPMP Bengkulu dalam tahap Pra-Instruksional juga menyiapkan/mengembangkan bahan ajar yang sesuai dengan kebutuhan dan karakteristik dari peserta Diklat. Menyiapkan bahan ajar yang sesuai dengan kebutuhan dan prilaku peserta diklat juga merupakan bagian yang menentukan tercapainya tujuan pembelajaran. Oemar Hamalik (2002:139) menyatakan bahan pengajaran merupakan bagian penting dalam proses belajar mengajar berkaitan dengan tercapainya tujuan pembelajaran, serta menentukan kegiatan-kegiatan belajar mengajar, serta dapat pula dirancang strategi apa yang akan dijalankan selama proses pembelajaran berlangsung. Oleh karena itu RPP/Silabus, perencanaan bahan ajar dan strategi pengajaran perlu mendapat pertimbangan yang cermat.

Dari penjelasan diatas dapat disimpulkan bahwa dalam tahap PraInstruksional meliputi mempersiapkan silabus, RPP, strategi dan bahan ajar. Dalam membuat silabus dan RPP harus memuat nilai-nilai sikap dan perilaku agar mengefektifkan proses pembelajaran dan pembentukan karakter peserta Diklat sesuai dengan apa yang direncanakan. Sedangkan bahan pengajaran perlu mendapat pertimbangan yang cermat karena bagian penting dalam proses belajar mengajar berkaitan dengan tercapainya tujuan pembelajaran.

\section{Tahap Instruksional}

Pada tahap Instruksional pada prinsipnya adalah menerapkan rencana yang telah disusun didalam RPP/Silabus pembelajaran. Langkah-langkah Pembelajaran yang dilakukan oleh widyaiswara LPMP Bengkulu dari hasil wawancara, observasi dan studi dokumentasi pada prinsipnya telah menerapkan langkah-langkah pembelajaran yaitu kegiatan awal, kegiatan inti, dan kegiatan akhir, yang secara spesifik adalah 1) merumuskan tujuan instruksional, 2) mempertimbangkan validitas dan relevansi materi, 3) Media pembelajaran yang gunakan dalam proses pembelajaran, 4) kesesuaian media dengan Tujuan pembelajaran, 5) Metode yang digunakan dalam proses pembelajaran, 6) Penyusunan Bahan Ajar, 7) Kegiatan pembelajaran untuk membuat peserta diklataktif, 8) Waktu yang digunakan untuk mencapai tujuan pembelajaran.

Pada tahap-tahap tersebut proses pembelajaran dapat merangsang peserta diklat agar pelaksanaan pembelajaran menjadi aktif dan timbul adanya interaksi yang baik. Hal ini sejalan dengan pendapatnya Masnur Muslich (2007:72) pada sub komponen pelaksanaan pembelajaran diarahkan pada tiga aspek kegiatan, yaitu 1) Kegiatan prapembelajaran 2) Kegiatan inti dan 3) Kegiatan penutup.

Metode dipersepsikan bahwa dalam menyampaikan suatu materi pembelajaran diperlukan metode agar pelaksanaan pembelajaran dapat terlaksana dengan baik. Apabila metode tidak diterapkan maka tujuan pembelajaran tidak akan tercapai. Rumiyati (2008: 56) menjelaskan metode pembelajaran dapat diartikan sebagai cara yang digunakan untuk mengimplementasikan rencana yang sudah disusun dalam bentuk kegiatan nyata dan 
praktis untuk mencapai tujuan pembelajaran. Terdapat beberapa metode pembelajaran yang dapat digunakan untuk mengimplementasikan strategi pembelajaran diantaranya: (1) Ceramah, (2) Demonstrasi, (3) Diskusi, (4) Simulasi, (5) Laboratorium, (6) Pengalaman lapangan, (7) Brainstorming, (8) Debat, dan sebagainya.

Sejalan dengan pendapat Sagala (Rumiyati, 2008: 60) cara yang digunakan dalam mengolah informasi yang berupa fakta, data, dan konsep pada proses pembelajaran yang mungkin terjadi dalam suatu strategi. Dalam pembelajaran, widyaiswara hendaknya pandai menggunakan atau memilih metode yang tepat yang sesuai dengan materi dan kondisi peserta Diklat. Metode pembelajaran yang digunakan oleh widyaiswara LPMP Bengkulu yaitu ceramah, tanya jawab, diskusi, dan problem solving. Menurut Sagala (Rumiyati, 2008: 60) metode yang digunakan dalam proses pembelajaran harus sesuai dengan karakteristik dari peserta diklat.

Dengan demikian ada banyak sekali metode yang dapat diterapkan dalam pembelajaran. Pemilihan metode dengan tepat akan menghasilkan tujuan pembelajaran yang maksimal. Selain itu widyaiswara juga harus dapat mengkondisikan peserta diklat pada proses pembelajaran yang lebih terarah dan bermakna.

Dalam hal pemanfaatan media pembelajaran, widyaiswara LPMP Bengkulu telah menggunakan media pembelajaran yang sesuai dengan tujuan yang ingin dicapai dan kebutuhan dari peserta diklat. Media Pembelajaran dipersepsikan sebagai alat bantu untuk memudahkan pemahaman peserta diklat dalam kegiatan pembelajaran. Maka dari itu, media merupakan bagian terpenting dalam proses pembelajaran yang dapat menumbuhkan minat dalam proses pembelajaran. Sebagaimana Sagala (Rumiyati, 2008: 55) mengemukakan bahwa media pembelajaran dimaknai sebagai alat komunikasi yang digunakan dalam proses pembelajaran untuk membawa informasi berupa materi ajar dari komunikator kepada komunikan sehingga peserta diklat menjadi lebih tertarik untuk mengikuti kegiatan pembelajaran. Pemilihan media pembelajaran yang tepat dan sesuai dengan kebutuhan peserta diklat dan karakteristik materi yang diajarkan dapat membantu pencapaian tujuan pembelajaran secara efektif. Dengan demikian, proses pembelajaran maupun hasilnya menjadi lebih berkualitas karena tujuan pembelajaran tercapai dengan baik.

Dengan demikian, adanya media peserta diklatakan menjadi lebih aktif dan terjadinya interaksi dalam proses pembelajaran sehingga materi pembelajaran dapat dicerna dengan mudah. Media untuk pembelajaran tidak hanya terbatas yang bersifat material namun juga dapat berupa immaterial, kondisional dan personal.

\section{Tahap Penilaian dan Tindak Lanjut (Evaluasi)}

Penilaian dalam proses pembelajaran Diklat bertujuan: 1) Mengetahui kedudukan peserta diklat dalam kelompok; 2) Sebagai balikan bagi widyaiswara untuk mengetahui ketepatan pemilihan metode dan program yang digunakan; 3) Mendiagnosa kendala yang dihadapi dalam proses pembelajaran; 4) Mendapatkan informasi yang dapat dijadikan bahan pertimbangan untuk menempatkan dan menentukan langkah berikutnya terhadap peserta diklat (Rumiyati: 2008: 39).

Penilaian yang dilakukan oleh widyaiswara dalam Diklat adalah Penilaian Proses, dan penilaian hasil tes. (Rumiyati, 
2008: 31) menyebutkan penilaian pembelajaran terhadap nilai proses hendaknya mencakup moralknowing, moral feeling, dan moral action. Sementara itu, Fathurrohman dan Wuri Wuryandani (2010: 86) menjelaskan penilaian dilakukan dengan menggunakan tes dan non-tes dalam bentuk tertulis maupun lisan, pengamatan kerja, pengukuran sikap, dan penilaian hasil karya.

Rumiyati (2008: 31) menyebutkan berdasarkan cara pelaksanaannya penilaian proses (non-tes) dikelompokkan meliputi skala sikap, check list, quesioner, catatan harian, dan portofolio. Penilaian yang dilakukan oleh widyaiswara menggunakan skala sikap. Penilaian ini dilakukan untuk mengamati perilaku peserta didik selama proses pembelajaran berlangsung. Dalam pengamatan ini, peserta diklat tidak perlu diberitahu bahwa mereka sedang diamati.

Sementara itu Penilaian Hasil (Teknik Tes) penilaian dalam ranah pembelajaran, peserta diklat tidak hanya diarahkan pada segi afektifnya saja, tetapi ada keseimbangan antara kognitif, afektif dan psikomotor. Jika dari segi afektifnya peserta diklat dapat tercapai tapi kognitifnya tidak akan menjadi suatu permasalahan dalam mengukur prestasi. Untuk mencapai pada pengetahuan, pemahaman, dan keterampilan serta watak harus mengacu pada pengembangan berbagai potensi peserta Diklat, baik secara kognitif, afektif, dan psikomotor. Penilaian yang digunakan oleh widyaiswara LPMP Bengkulu adalah penilaian secara tertulis. Penilaian secara tertulis ini, peserta Diklat dapat menjawab soal-soal berbentuk pilihan ganda, isian singkat, dan uraian/essay.

Dari uraian diatas dapat disimpulkan bahwa dalam tahap penilaian ada dua macam yaitu penilaian tahap proses dan tahap hasil. Pada tahap proses dilakukan saat peserta didik mengikuti pembelajaran sedangkan untuk penilaian hasil dilakukan untuk mengukur sejauh mana pemahaman siswa yang dilakukan dengan soal tes.

\section{PENUTUP \\ Kesimpulan}

Dari hasil penelitian dan pembahasan yang telah dikemukakan diatas dapat disimpulkan sebagai berikut:

1. Pada Tahap Pra-Instruksional Widyaiswara LPMP Bengkulu melakukan langkah-langkah: a) Persiapan untuk melaksanakan Diklat yang ditunjukkan dengan surat tugas dan arahan dari pimpinan, b) Menyusun Rencana Pelaksanaan Pembelajaran (RPP) dan Silabus Pembelajaran, c) Menyusun Strategi yang akan dijalankan dalam proses pembelajaranDiklat, d) Mempelajari perilaku awal (entering behavior) dan kebutuhan peserta Diklat sebelum Proses pembelajaran berlangsung

2. Pada Tahap Instruksional Widyaiswara melakukan langkah-langkah: a) Menetapkan Rumusan tujuan instruksional dengan memperhatikan kebutuhan peserta Diklat dan kemampuan mereka dalam memahami materi Diklat, b) Melakukan Validitas dan relevansi materi yang akan disampaikan kepada peserta Diklat, c) Menggunakan Media pembelajaran yang bervariasi dalam proses pembelajaran Diklat, d) Telah menyesuaikan antara media yang digunakan dengan Tujuan Pembelajaran, e) Telah menggunakan metode yang bervariasi dalam proses pembelajaran pada Diklat di LPMP Bengkulu, f) Menetapkan Sumber/Bahan ajar yang sesuai dengan kebutuhan peserta Diklat, g) Penggunaan waktu yang tepat dan sesuai untuk mencapai tujuan pembelajaran, h) Telah membuat 
peserta Diklat aktif dalam mengikuti proses pembelajaran

3. Pada Tahap Penilaian dan Tindak Lanjut (Evaluasi) widyaiswara LPMP Bengkulu melakukan: a) Evaluasi terhadap peserta Diklat, b) Bentuk evaluasi yang diberikan kepada peserta Diklat adalah dengan penilaian proses dan penilaian akhir melalui soal tes, 3) Evaluasi yang dilakukan telah dapat mencapai tujuan pembelajaran yang diinginkan.

\section{Saran}

\section{a. Bagi Widyaiswara}

Widyaiswara sebagai pelaksana pembelajaran di dalam Diklat harus selalu meningkatkan pemahaman dan kemampuan seperti melakukan inovasi dalam pembelajaran; meningkatkan kualifikasi pendidikan dengan melanjutkan pendidikan ke jenjang yang lebih tinggi.

\section{b. Bagi Peserta Diklat}

Peserta Diklatharus memahami bahwa Diklatbukanlah tempat untuk sekedar diikuti dan mendapatkan hasil, namun harus dipahami hasil yang didapatkan harus mampu merubah perilaku dan cara mengajar peserta Diklat setelah sampai di sekolah masing-masing. Sehingga disarankan kepada peserta Diklatuntuk senantiasa memperbaiki pola mengajar setelahmengikuti Diklat

\section{c. PenelitiSelanjutnya}

Dari hasil penelitian ini menunjukan bahwa penulis hanya terbatas mengungkapkan bagaimana widyaiswara LPMP Bengkulu menerapkan proses pembelajaran pada Diklat di LPMP Bengkulu, sementara peneliti selanjutnya bisa mengembangkan penelitian dengan mempedomani penelitian yang telah penulis jalankan ini.

\section{DAFTAR PUSTAKA}

Arikunto, Suharsimi. 2002. "Prosedur Penelitian suatu Pendekatan Praktek”. Jakarta: Rineka Cipta.

Arifin, Anwar. 1984. "Strategi Komunikasi”. Bandung: Armico.

A.W. Widjaya. 1997. "Komunikasi dan Hubungan Masyarakat”. Jakarta: PT. Bumi Aksara.

Berlo, David K. 1960. The Process of Communication: An Introduction to Theory and Practice. Holt, Rinehart and Winston, New York

Bungin, Burhan. 2003. "Analisis Data Penelitian Kualitatif“. Jakarta: PT Raja Grafindo Persada.

Cangara, Hafied. 1998. "Pengantar Ilmu Komunikasi”. Jakarta: Rajawali Press.

Cangara, Hafied. 2013. "Perencanaan Dan Strategi Komunikasi”. Jakarta: PT. Raja Grafindo Persada.

Dahar, Ratna Wills. 1996. "Teori-teori Belajar”. Jakarta: PT. Erlangga.

Devito, Joseph A. 1997. "Komunikasi Antar Manusia Kuliah Dasar". Alih Bahasa Agus Maulana. Jakarta: Professional Book.

E.Mulyasa.2004. "Implementasi Kurikulum 2004 Panduan Pembelajaran KBK”. Bandung: PT. Remaja Rosdakarya

Effendy, Onong Uchjana. 1981. "Dimensidimensi Komunikasi”. Bandung: Penerbit Alumni. Jonathans, Errol.

Effendy, Onong Uchjana. 1984. "Komunikasi Teori dan Praktek". Bandung: PT. Remaja Rosda Karya.

Effendy, Onong Uchjana. 1992. “Dinamika Komunikasi”. Bandung: PT. Remaja Rosda Karya.

Effendy, Onong Uchjana. 1993. "Ilmu, Teori \& Filsafat Komunikasi”. Bandung : PT. Citra Aditya Bakti 
Effendy, Onong Uchjana. 2002. "Ilmu Komunikasi Teori dan Praktek". Bandung: PT. Remaja Rosda Karya.

Effendy, Onong Uchjana. 2003. "Ilmu, Teori dan Filsafat Komunikasi". Bandung : Citra Aditya.

Effendy, Onong Uchjana. 2009. "Ilmu Komunikasi, Teori dan Praktek". Bandung: PT. Remaja Rosdakarya.

Iriantara Yosal, 2014. "Komunikasi Pembelajaran”. Bandung: PT Remaja Rosdakarya.

Iriantara Yosal, Usep Syaripudin. 2013. “Komunikasi Pendidikan”. Bandung: PT Remaja Rosadakarya Offset.

Mulyana, Deddy. 2000. "Ilmu Komunikasi Suatu Pengantar”. Bandung: Remaja Rosdakarya.

Moloeng, lexy J. 2004. "Metode Penelitian Kualitatif”. Bandung: Remaja Rosdakarya.

Moelong, Lexy J. 2001. “Metodologi Penelitian Kualitatif”. Bandung: PT Remaja Rosda Karya.

James

B. Quinn and

Jhon Voyer.1999. "Strategy. Process". New York: Oxford University Press.

Nana. 1989. "Dasar-dasar Proses Belajar Mengajar". Bandung: Sinar Baru Algesindo.

Nimmo, Dan. 1979. "Communication Year”. Book 3. New Jersey: Published by The International Communication Assosiation.

Nasution, Prof. Dr. S. 2003. "Metode Penelitian Naturalistik Kualitatif”. Bandung: Tarsito.

Nuryani, R. 2005. "Strategi Belajar Mengajar Biologi”. Malang: Universitas Negeri Malang.

Pawit M. Yusuf. 2010. "Komunikasi Instruksional(Teori dan Praktik)”. Jakarta: PT. Bumi Aksara.

LPMP Bengkulu. 2013. "Profil LPMP”. Bengkulu: LPMP Bengkulu.
Ruslan, Rosady. 2002. "Kiat \& Strategi Kampanye Public Relations". Jakarta: PT. Raja Grafindo Persada.

Ruslan, Rosady. 2005. "Kampanye Public Relations”. Jakarta: PT. Raja Grafindo Persada.

Sendjaya, S. 1993. "Teori Komunikasi”. Jakarta: Universitas Terbuka.

Sudijono, Anas. 1996. "Pengantar Evaluasi Pendidikan”. Jakarta: PT. Raja Grafindo Persada.

Sugiyono. 2007."Metode Penelitian Administrasi". Bandung: Cetakan Ke15. CV. Alfabeta.

Supriadie Didi, Darmawan Deni. 2012. "Komunikasi Pembelajaran". Bandung: PT. Remaja Rosda karya.

Suparman, Atwi. 1991. "Desain instruksional”. Jakarta: Departemen Pendidikan dan Kebudayaan Direktorat Jenderal Pendidikan Tinggi.

Suranto. 2005. "Komunikasi Perkantoran”. Yogyakarta: Media Wacana

Tubbs, L. Stewart \& Sylvia Moss. 1996."Human

Communication,Prinsip - Prinsip Dasar". Bandung: PT. Remaja Rosdakarya

Wahyudi, Agustinus Sri. 1996. "Manajemen Strategik Pengantar Proses Berpikir Strategik”. Cetakan pertama. Jakarta: Binarupa Aksara,

Yusup, Pawit M. 1990. "Komunikasi Pendidikan dan Komunikasi Instruksional”. Bandung : PT. Remaja Rosdakarya.

http://irhamnurhalim.wordpress.com/2012/1 1/01/arti-penting-komunikasi/, diakses 4 Februari 2015 pukul 09.15 WIB.

http://pelatihanguru.net/apa-itu-jenis-jenistahap-komunikasi-dan-pengertianproses-komunikasi, diakses 
http://id.shvoong.com/socialsciences/communication-mediastudies/2166075-pengertian-komunikasiefektif/, diakses 5 Februari 2015 pukul 09.30 WIB.

http://www.scribd.com/doc/20248464/SifatBentuk-Dan-Strategi-Komunikasi, diakses 5 maret 2015 pukul 15.00 WIB.

Peraturan Presiden Nomor 7 Tahun 2005 tentang Rencana Pembangunan Jangka Menengah (RPJM) Tahun 2004-2009.
Peraturan Menteri Negara Pendayagunaan Aparatur Negara Nomor: 14 Tahun 2009 Tentang Jabatan Fungsional Widyaiswara Dan Angka Kreditnya Dengan Rahmat Tuhan Yang Maha Esa Menteri Negara Pendayagunaan Aparatur Negara

Undang-Undang Republik Indonesia Nomor 20 Tahun 2003 Tentang Sistem Pendidikan Nasional

http://tulisanterkini.com/artikel/artikelilmiah/8708-tahap-tahap-prosesdalam-pembelajaran.html 